\title{
Addictive Substances and Sleep: More Research is Needed
}

\author{
Ravi Gupta ${ }^{1}$ (D) Seithikurippu R. Pandi-Perumal ${ }^{2}$ (])
}

Published online: 4 December 2018

(c) Springer Nature Singapore Pte Ltd. 2018

Since a long time, addictive substances have been found to affect sleep quantity, quality, and sleep architecture. In addition, certain substances have been found to induce other physiological processes during sleep, thereby affecting the quality or quantity of sleep. However, we have limited data to suggest that addictive substances may influence sleep quality and quantity either by inducing or relieving other sleep disorders.

Restless legs syndrome (RLS) also known as Willis-Ekbom disease (WED), named after the doctor who first described it in 1945 [1] is a less understood, but a commonly treatable chronic sleep disorder that is characterized by severe sensory-motor dysfunction. The affected individuals often report an urge to move legs, especially at night with worsening of symptoms at rest and an improvement by movement [2]. This disorder has been linked to the dopamine abnormalities in the brain, which in turn has been found to be regulated by opioid receptors [3, 4]. Furthermore, opioid has found a place in the management of RLS in selected cases [5].

Opioid withdrawal presents with muscle aches and pains, often along with the restlessness [6]. These features often overlap with the symptoms of RLS and considering the neurobiological underpinnings, it may be possible that some of the patients develop RLS during opioid withdrawal. Case reports and case series suggested that RLS is seen in the patients during opioid withdrawal, including dextropropoxyphene and tramadol $[7,8]$. However, large studies in this area are limited and to the best of our knowledge, only one study is available that suggested the prevalence of RLS as $13 \%$ among patients with opiate withdrawal [9]. Recognition of RLS and its distinction from myalgia that occurs during opioid/opiate withdrawal are important for a number

Ravi Gupta

sleepdoc.ravi@gmail.com

1 Department of Psychiatry, All India Institute of Medical Sciences, Veerbhadra Marg, Rishikesh 249203, India

2 Somnogen Canada Inc., College Street, Toronto, ON, Canada of reasons. First, RLS may induce sleep disturbance in these patients, which is completely amenable to treatment $[7,8]$. Addressing the RLS may thus facilitate the detoxification process. Second, in contrast to myalgia, which generally lasts for only initial 3-5 days after opiate/opioid withdrawal, symptoms of RLS may persist for a longer duration, thus, requiring treatment to be continued during the post-detoxification process $[7,8]$.

A recent study suggested that RLS is seen in around 50\% subjects during opioid withdrawal [10]. Moreover, there is evidence that concurrent cannabis use or cannabis itself may either prevent or ameliorate symptoms of RLS $[10,11]$.

Similarly, tobacco, in particular, smoking is considered a risk factor for the development of RLS [12]. However, contradictory data are also available suggesting improvement in RLS following tobacco chewing and the absence of effect of smoking over RLS [13-16].

The antinociceptive and psychoaffective effects of cannabis are well known. The potential benefits and the efficacy of cannabis use in the treatment of RLS was first reported in a case study [11]. In a subjective evaluation, all six patients reported an improvement in sleep quality and symptomatic relief of RLS with minimal side effects.

The effect of medical cannabis in the sleep field is gaining much attention. Cannabinoids work on the endocannabinoid system (ECS). Among the various cannabinoids, delta-9 tetrahydrocannabinol (THC) and cannabidiol (CBD) are extensively studied. Cannabinoids that work on the human ECS act through two main receptors, namely the CB1 and CB2 receptors. One such synthetic cannabinoid is dronabinol, which has undergone preclinical and clinical studies [17-19]. However, with the limited safety profile of medical cannabis in the field of sleep medicine, the American Academy of Sleep Medicine (AASM) has released a position statement, which clearly pointed out the lack of evidence on the use of medical cannabis and further cautioned that "medical cannabis and/or its synthetic extracts should not be used for the treatment of OSA due to unreliable delivery methods and insufficient evidence of effectiveness, tolerability, and safety" [20]. However, it has been argued that further 
longitudinal and controlled trials are needed to fully explore the potential use of cannabinoids in the sleep field [21].

In conclusion, this is an important area that requires attention. There is a need to conduct two kinds of studies for a better understanding-experimental as well as epidemiological. Robust data generated from both kinds of trials simultaneously will help us to understand sleep physiology in a better manner.

\section{References}

1. Ekbom KA. Restless legs. Stockholm: Ivar Haeggströms; 1945. p. 123.

2. Allen RP, Picchietti DL, Garcia-Borreguero D, Ondo WG, Walters AS, Winkelman JW, Zucconi M, Ferri R, Trenkwalder C, Lee HB, International Restless Legs Syndrome Study Group. Restless legs syndrome/Willis-Ekbom disease diagnostic criteria: updated International Restless Legs Syndrome Study Group (IRLSSG) consensus criteria-history, rationale, description, and significance. Sleep Med. 2014;15(8):860-73. https://doi.org/10.1016/j.sleep 2014.03.025.

3. Sun YM, Hoang T, Neubauer JA, Walters AS. Opioids protect against substantia nigra cell degeneration under conditions of iron deprivation: a mechanism of possible relevance to the Restless Legs Syndrome (RLS) and Parkinson's disease. J Neurol Sci. 2011;304(1-2):93-101. https://doi.org/10.1016/j.jns.2011.02.003.

4. Fulda S, Wetter TC. Where dopamine meets opioids: a metaanalysis of the placebo effect in restless legs syndrome treatment studies. Brain. 2008;131(Pt 4):902-17. https://doi.org/10.1093/ brain/awm244.

5. Aurora RN, Kristo DA, Bista SR, Rowley JA, Zak RS, Casey KR, Lamm CI, Tracy SL, Rosenberg RS, American Academy of Sleep Medicine. The treatment of restless legs syndrome and periodic limb movement disorder in adults-an update for 2012: practice parameters with an evidence-based systematic review and meta-analyses: an American Academy of Sleep Medicine Clinical Practice Guideline. Sleep. 2012;35(8):1039-62. https://doi. org/10.5665/sleep.1988.

6. American Psychiatric Association. Diagnostic and statistical manual of mental disorders. 5th ed. Arlington: American Psychiatric Association; 2013.

7. Ghosh A, Basu D. Restless legs syndrome in opioid dependent patients. Indian J Psychol Med. 2014;36(1):85-7. https://doi. org/10.4103/0253-7176.127262.

8. Park YM, Park HK, Kim L, Lee HJ, Kang SG. Acute-withdrawal restless legs syndrome following abrupt cessation of short-term tramadol. Psychiatry Investig. 2014;11(2):204-6. https://doi. org/10.4306/pi.2014.11.2.204.
9. Scherbaum N, Stüper B, Bonnet U, Gastpar M. Transient restless legs-like syndrome as a complication of opiate withrawal. Pharmacopsychiatry. 2003;36(2):70-2. https://doi. org/10.1055/s-2003-39047.

10. Gupta R, Ali R, Ray R. Willis-Ekbom disease/restless legs syndrome in patients with opioid withdrawal. Sleep Med. 2018;45:39-43. https://doi.org/10.1016/j.sleep.2017.09.028.

11. Megelin T, Ghorayeb I. Cannabis for restless legs syndrome: a report of six patients. Sleep Med. 2017;36:182-3. https://doi. org/10.1016/j.sleep.2017.04.019.

12. Benediktsdottir B, Janson C, Lindberg E, Arnardóttir ES, Olafsson I, Cook E, Thorarinsdottir EH, Gislason T. Prevalence of restless legs syndrome among adults in Iceland and Sweden: lung function, comorbidity, ferritin, biomarkers and quality of life. Sleep Med. 2010;11(10):1043-8. https://doi.org/10.1016/j.sleep .2010.08.006.

13. Lahan V, Ahmad S, Gupta R. RLS relieved by tobacco chewing: paradoxical role of nicotine. Neurol Sci. 2012;33(5):1209-10. https://doi.org/10.1007/s10072-011-0882-z.

14. Vizcarra-Escobar D, Mendiola-Yamasato A, Risco-Rocca J, Mariños-Velarde A, Juárez-Belaunde A, Anculle-Arauco V, Rivera-Chira M. Is restless legs syndrome associated with chronic mountain sickness? Sleep Med. 2015;16(8):976-80. https://doi. org/10.1016/j.sleep.2015.03.013.

15. Budhiraja P, Budhiraja R, Goodwin JL, Allen RP, Newman AB, Koo BB, Quan SF. Incidence of restless legs syndrome and its correlates. J Clin Sleep Med. 2012;8(2):119-24. https://doi. org/10.5664/jcsm. 1756.

16. Gupta R, Ulfberg J, Allen RP, Goel D. High prevalence of restless legs syndrome/Willis Ekbom Disease (RLS/WED) among people living at high altitude in the Indian Himalaya. Sleep Med. 2017;35:7-11. https://doi.org/10.1016/j.sleep.2017.02.031.

17. Calik MW, Carley DW. Effects of cannabinoid agonists and antagonists on sleep and breathing in sprague-dawley rats. Sleep. 2017. https://doi.org/10.1093/sleep/zsx112.

18. Kolla BP, Mansukhani MP, Olson EJ, St Louis EK, Silber MH, Morgenthaler TI. Medical cannabis for obstructive sleep apnea: premature and potentially harmful. Mayo Clin Proc. 2018;93(6):689-92.

19. Scharf EL, Ebbert JO, Hurt RT. Comment on medical cannabis for obstructive sleep apnea: premature and potentially harmful. Mayo Clin Proc. 2018;93(11):1688-9. https://doi.org/10.1016/j. mayocp.2018.08.017.

20. Ramar K, Rosen IM, Kirsch DB, Chervin RD, Carden KA, Aurora RN, Kristo DA, Malhotra RK, Martin JL, Olson EJ, Rosen CL, Rowley JA, American Academy of Sleep Medicine Board of Directors. Medical cannabis and the treatment of obstructive sleep apnea: an American Academy of Sleep Medicine position statement. J Clin Sleep Med. 2018;14(4):679-81.

21. Babson KA, Sottile J, Morabito D. Cannabis, cannabinoids, and sleep: a review of the literature. Curr Psychiatry Rep. 2017;19(4):23. https://doi.org/10.1007/s11920-017-0775-9. 